\title{
Study on the Growth and Development of two Dragon Fruit (Hylocereus undatus) Genotypes
}

\author{
M. M. Alam Patwary ${ }^{1 *}$, M. H. Rahman ${ }^{1}$, H. Barua ${ }^{1}$, S. Sarkar ${ }^{2}$ and Md. Shamsul Alam ${ }^{3}$ \\ ${ }^{1}$ Agricultural Research Station, Bangladesh Agricultural Research Institute (BARI), Pahartali, \\ Chittagong; ${ }^{2}$ Department of Agricultural Botany, Sher-e-Bangla Agricultural University, Dhaka; \\ ${ }^{3}$ Planning and Evaluation Division, Bangladesh Agricultural Research Institute, Gazipur, Bangladesh \\ *Corresponding author and Email: kbdmahbub69@gmail.com
}

Received: 08 July $2013 \quad$ Accepted: 06 December 2013

\begin{abstract}
A preliminary investigation was carried out under the AEZ- 29 at the Agricultural Research Station, Bangladesh Agricultural Research Institute (BARI), Pahartali, Chittagong during December 2010 to May 2012 to evaluate two dragon fruit genotypes. The longer plant $(272.13 \mathrm{~cm})$ was recorded in HUP 002 while it was $263.34 \mathrm{~cm}$ in HUP 001 after one and half year of planting. Flower bud emergence took place after 17 months (on 9 May, 2012) in HUP 001, while it commenced in HUP 002 after 15 months (on 22 March, 2012). Flower bud required 28 days bloom from emergence and the fruit matured after 33 days from anthesis in HUP 001, while that required 35 days for HUP 002 and fruits become matured after 32 days from anthesis. Larger number (8) of flowers per plant was observed in HUP 002 while the lower was noted in HUP 001(6). Numerous anthers were observed below the stigma with attractive white petals in both the varieties. The fruit weights ranged from $200-375$ in HUP 002 but $150-200 \mathrm{~g}$ in HUP 001 . The edible portions were 91.0 and 92.0 with 12.0 and $11.4 \%$ TSS in HUP 001 and HUP 002, respectively. Fruit pulp colour was white in HUP 001 while red in HUP 002 .
\end{abstract}

Keywords: Dragon fruit, plant growth, floral and fruit characteristics

\section{Introduction}

The origin of Hylocereus spp. is the tropical and sub-tropical forest regions of Mexico and Central and South America (Mizrahi et al., 1997). From the centre of its origin, dragon fruit spread to tropical and sub-tropical America, Asia, Australia and the Middle East. It is cultivated in at least 22 countries of the tropics, such as, Australia, Cambodia, China, Israel, Japan, Nicaragua, Peru, Philippines, Spain, Sri Lanka, Taiwan, Thailand, South Western USA and Vietnam etc. (Mizrahi and Nerd, 1999; Novel and Barrera, 2002).
Dragon fruit $(H$. undatus) is popular in South East Asia. It is an edible vine cactus species belonging to the family Cactaceae which has received world wide recognition - first, as an ornamental plant and then as a fruit crop. It is well known for its rich nutrient contents specially vitamin $\mathrm{C}$, phosphorus, calcium as well as its antioxidant characteristics (Morton, 1987). The fresh fruit contain 82.5-83.0\% moisture, $0.16-0.23 \%$ protein, $0.21-0.61 \%$ fat, $0.7-0.9 \%$ fibre. Hundred gram fresh fruit pulp contains 6.3-8.8 mg calcium, 30.2-36.1 mg phosphorous, 0.5-0.61 mg iron and 8-9 $\mathrm{mg}$ vitamin C (Taiwan Food Industry Development and Research 
Authorities, 2005). It is perennial and fast growing climber with triangular or rarely four or five ridged stems. The stem is fleshy, vine like with many branched segments. Each segment has three wavy wings and 1-3 spines or sometimes spineless. These spines form aerial roots which adhere, helps to climb and keep the plant erect. Its fruit is beautiful with bright red skin studded with green scales and white or red flesh with numerous tiny black seeds. The flower is so beautiful that its nick name is "Novel woman" or "Queen of the night".

In Bangladesh, dragon fruits were introduced by some private entrepreneurs from different countries for growing as ornamental plants. Some of the elite farmers in different places of Bangladesh like Ashulia, Dhaka and Halda Valley Tea State, Fatikchari, Chittagong already started its commercial cultivation. Research on it has already been started at BARI, Gazipur \& the Germplasm Center, BAU, Mymensingh. Already mass media like different TV channels and newspapers have drawn public attention of Bangladesh regarding the cultivation of this nutritious fruit. However, published information on this crop in Bangladesh is very scanty. Hence, research on this crop should be emphasized. Therefore, the present investigation was undertaken to study the growth behavior, floral biology and fruiting behavior of this newly introduced crop.

\section{Materials and Methods}

Cuttings of dragon fruit were collected from the Germplasm Centre of Bangladesh Agricultural University (BAU), Mymensingh as HUP 001 and Halda Valley Tea state, Fatikchari, Chittagong as HUP 002 and twelve plants of each genotypes were planted during December 2010 at a spacing of $2 \times 2 \mathrm{M}$ (Jacobs and Dimitri, 1999) at the Agricultural Research Station, BARI, Pahartali, Chittagong. The plants were supported by RCC pillars having a base at the top of the pillar to allow the plants to grow properly. Manures and fertilizers were applied as per recommendation made by Rahim et al., (2009) @ 40 kg cowdung/pit \& 50-100-100-1010-10 g/pit of Urea, TSP, MoP, gypsum, borax and zinc-sulphate, respectively. The full amounts of fertilizers were applied at the time of land preparation as basal dose. The cuttings were planted after 30 days of fertilizer application. Irrigation and other intercultural operations were done as per requirements. Dithane M-45 was applied @ 2 g/liter of water to control red rust disease.

Data on the plant height, number of segments and the number of side segments were collected at every 30 days interval. Other parameters on days after transplanting to anthesis, time of anthesis, duration of anthesis, number of calyx, number of petals, stigma segments, length of flower $(\mathrm{cm})$, colour of anthers, colour of stigma, petal colour, number of anthers, number of flowers per plant, date of harvest, days to harvest, number of fruits per plant, fruit weight $(\mathrm{g})$, fruit length $(\mathrm{cm})$, fruit breadth $(\mathrm{cm})$, pulp colour, edible portion (\%) and total soluble solids (TSS) were recorded. Five fruits were used as sample for measuring the fruit data. Data were analyzed statistically following paired $\mathrm{T}$ test.

\section{Results and Discussion}

The mean data of all the parameters were calculated and are presented in Tables 1 and 2 and Figures 1, 2 and 3. The taller plants (272.1 $\mathrm{cm})$ were recorded in HUP 002 while $263.3 \mathrm{~cm}$ in HUP 001 after one and half year (Fig. 1). Number of segments per plant was 7.2 in HUP 002 while 5.7 in HUP 001 (Fig. 2). Number of side segments per plant was 5.11 in HUP 002 while it was 4.70 in HUP 001 (Fig. 3). Flower bud emergence took place after 17 months (on 9 May, 2012) in HUP 001 while after 15 months (on 22 March, 2012) in HUP 002. Flower bud required 29 days to bloom in HUP 001 while 35 days in HUP 002. Anthesis started at 3-4 pm and continued 4-5 hours to anthesis. Pushpakumara et al. (2005) reported similar results. Higher number of flower (8) was observed in HUP 002 while the lower number (6) was counted in HUP 001. The flower was $30 \mathrm{~cm}$ long with 65 calyx and 22 petals in HUP 002 while those were 28 $\mathrm{cm}$ long with 53 calyx and 18 petals in HUP 001 (Table 1). 


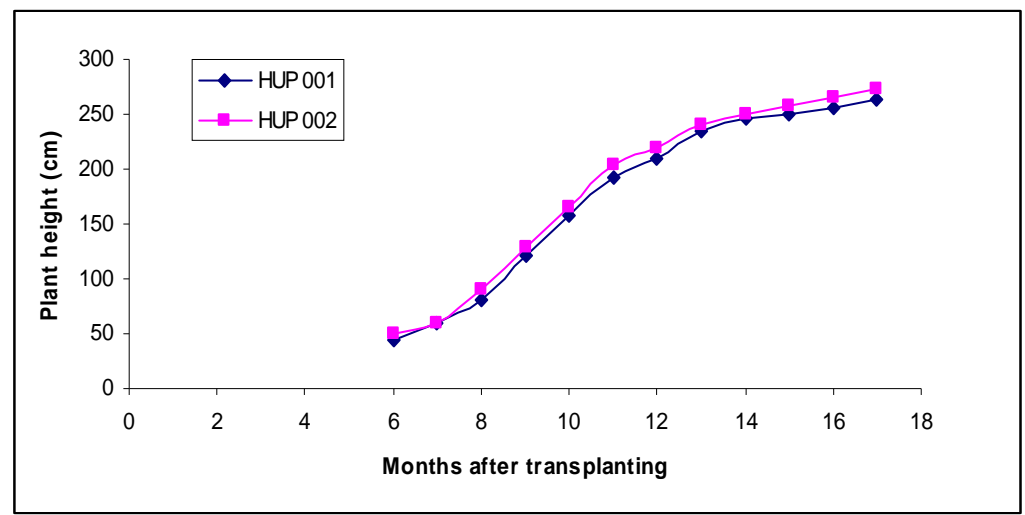

Fig. 1. Plant height of the studied dragon fruit genotypes

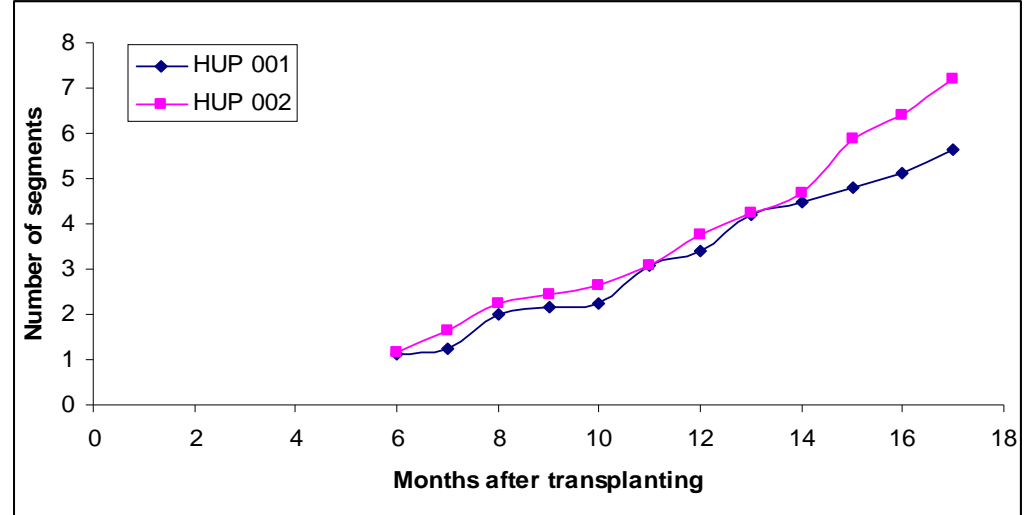

Fig. 2. Number of segments of the studied dragon fruit genotypes

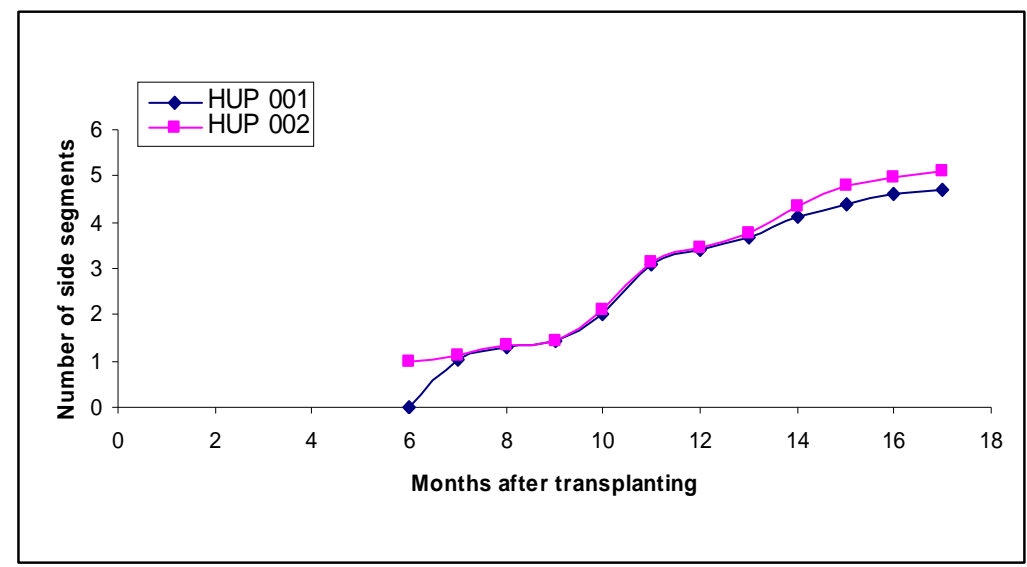

Fig. 3. Number of side segments of the studied dragon fruit genotypes 
Table 1. Floral characteristics of the studied two dragon fruit genotypes

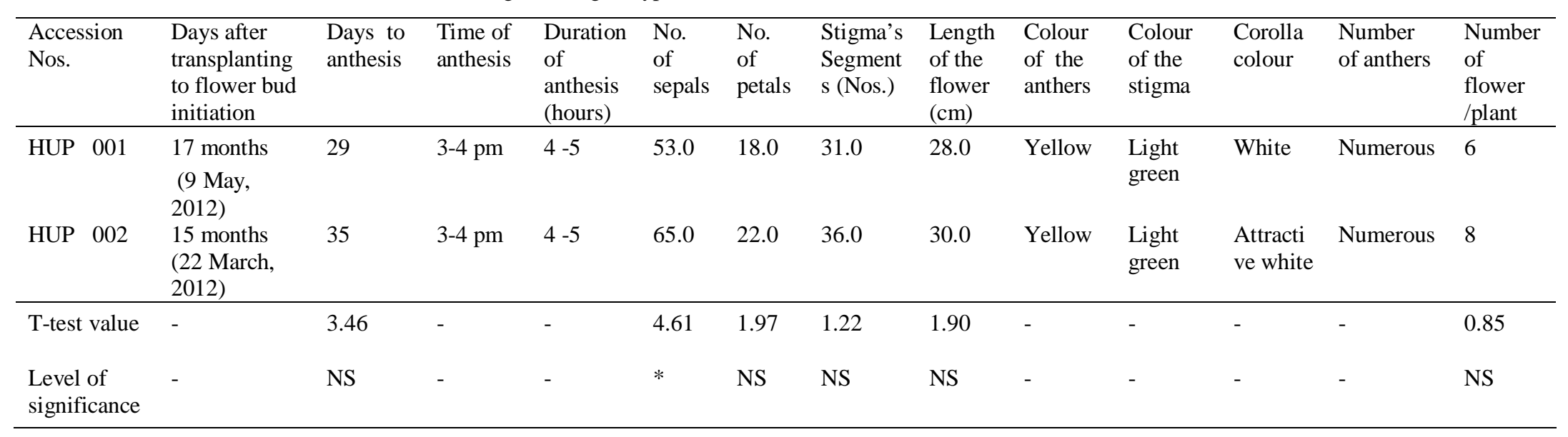

* significant at $5 \%$ level of degree of freedom.

Table 2. Fruit characteristics of the studied two dragon fruit genotypes

\begin{tabular}{|c|c|c|c|c|c|c|c|c|c|}
\hline Accession Nos. & $\begin{array}{l}\text { Days to fruit } \\
\text { harvest from } \\
\text { anthesis }\end{array}$ & $\begin{array}{l}\text { No. of fruits/ } \\
\text { plant }\end{array}$ & Wt. of fruit (g) & $\begin{array}{l}\text { Fruit length } \\
(\mathrm{cm})\end{array}$ & $\begin{array}{l}\text { Fruit } \\
\text { breadth }(\mathrm{cm})\end{array}$ & $\begin{array}{l}\text { Skin } \\
\text { colour at } \\
\text { maturity }\end{array}$ & $\begin{array}{l}\text { Pulp } \\
\text { colour }\end{array}$ & $\begin{array}{l}\text { Edible } \\
\text { portion } \\
(\%) \\
\end{array}$ & $\begin{array}{l}\text { TSS } \\
(\%)\end{array}$ \\
\hline HUP 001 & 33 (09.07.2012) & 5 & 171.0 & 9.6 & 5.9 & red & White & 91.0 & 11.2 \\
\hline HUP 002 & $32(29.05 .2012)$ & 6 & $\begin{array}{l}(150-200) \\
300.0 \\
(200-375) \\
\end{array}$ & 8.5 & 8.60 & red & red & 92.0 & 12.0 \\
\hline T-test value & 0.57 & 0.57 & 70.81 & 0.60 & 1.49 & - & - & 0.24 & 0.36 \\
\hline $\begin{array}{l}\text { Level of } \\
\text { significance }\end{array}$ & NS & NS & $* *$ & NS & NS & - & - & NS & NS \\
\hline
\end{tabular}

** significant at $1 \%$ level of degree of freedom. 

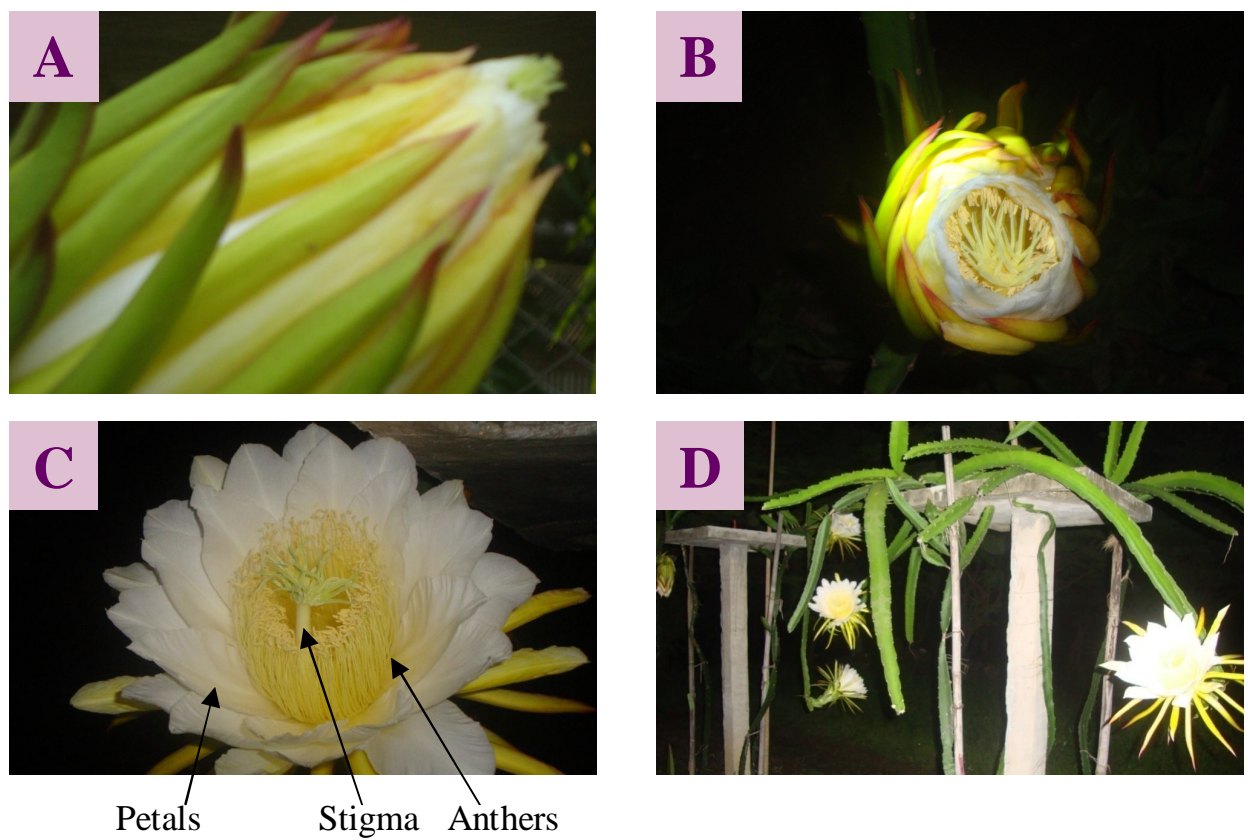

Fig. 4. A. Anthesis started, B. Mid phase of flowering anthesis, C. Completion of anthesis showing different flower parts and D. Dragon fruit plant with flowers after anthesis (same for both the genotypes)
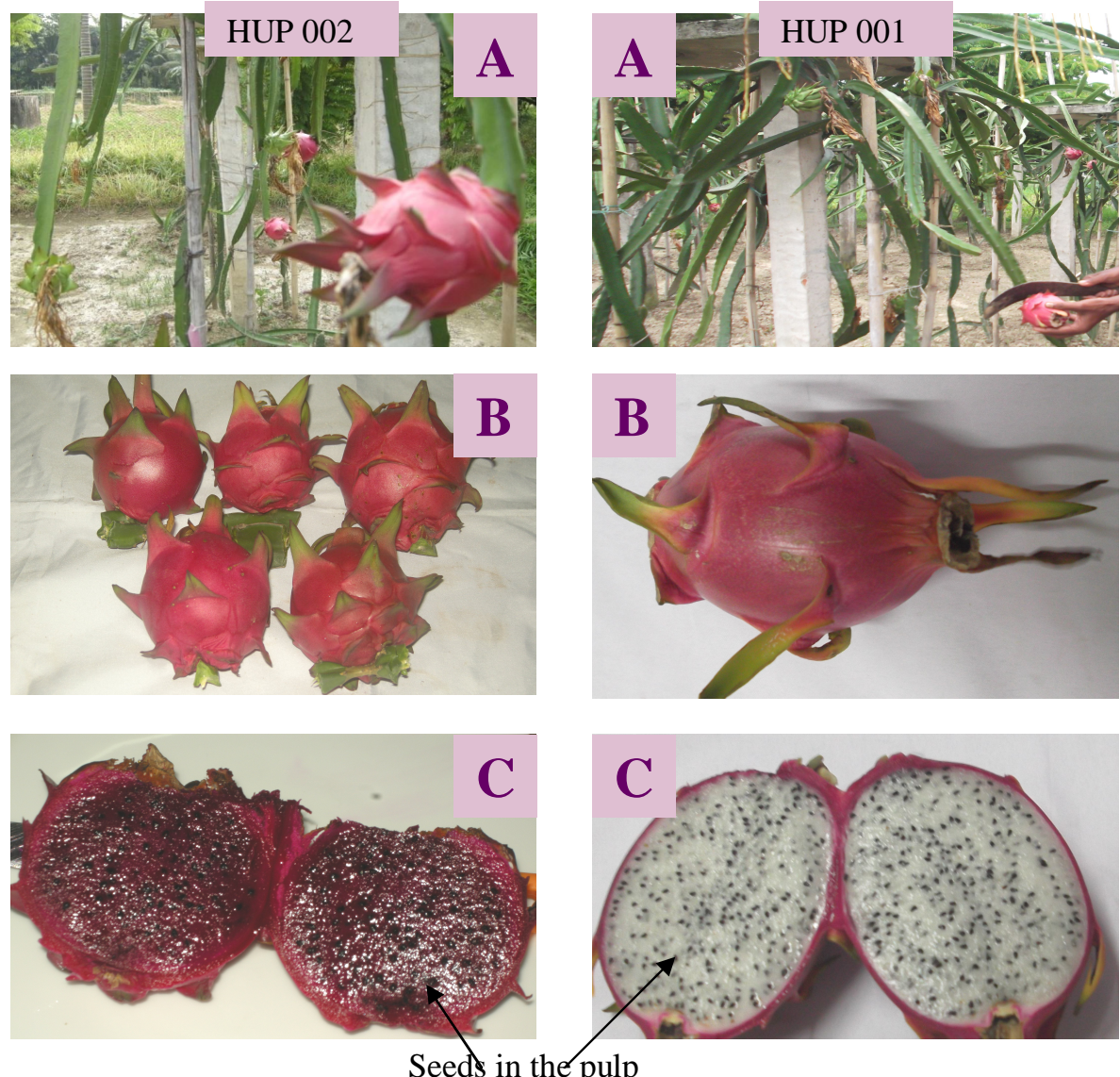

Fig. 5. A. Dragon fruit plant with ripe fruits, B. Harvested fruits and C. Cross-section of dragon fruit 
Similar findings were reported in Wikipedia (2012) mentioning the length of flower 25-30 $\mathrm{cm}$, which is supportive for the results of the present study. Numerous anthers were observed below the stigma with attractive white petals (Fig. 4).

The fruit changes its peel colour from green to red at mature stage in both the genotypes. Matured fruits were harvested after 33 days of anthesis in HUP 001 while after 32 days in HUP 002. Nerd et al. (1999) and Pushpakumara et al. (2005) also found that ripened fruits could be harvested between 30-50 days after pollination. Fruit weight ranged from $200-375 \mathrm{~g}$ in HUP 002 while from 150-200 $\mathrm{g}$ in HUP 001. Jacobs (1999) mentioned that fruit weights ranged from $150-600$ g. Fruit shape was oval in HUP 001 while round in HUP 002. Fruit pulp colour was red in HUP 002 whereas white in HUP 001. Rahim et al. (2009) also mentioned variable pulp colour in dragon fruits. Numerous small black tiny seeds similar to black cumin were scattered in the pulp in both the genotypes (Fig. 5). Edible portion was 92.0 in HUP 002 while $91.0 \%$ in HUP 001. TSS were 11.20 and $12.0 \%$ in HUP 001 and HUP 002, respectively (Table 2). These results are in accordance with those of Islam et al. (2012) who reported $11.0 \%$ TSS in fresh dragon fruit juice.

\section{Conclusions}

From the above results, it is evident that dragon fruit could be grown successfully in chittagong region. However, considering the number of flowers, weight of fruit and other characteristics, the genotype HUP 002 was found promising. Research could be strengthened on different cultural practices as well as varietal development.

\section{References}

Islam, M. Z., M. T. H. Khan, M. M. Hoque and M. M. Rahman. 2012. Studies on the Processing and Preservation of Dragon fruit (Hylocereus undatus) Jelly. The Agriculturist, 10 (2): 29-35.
Jacobs and Dimitri. 1999. Pitaya (Hylocereus undatus), a potential new crop for Australia. Australian New Crops Newsletter, 11: 16.3.

Mizrahi, Y and A. Nerd. 1999. Climbing and columnar cacti: New arid land fruit crops. In: Janick, J. (ed) Perspective on new crops and new uses. ASHS press, American Society of Horticultural Science, Alexandria, Verginia: 358-366.

Mizrahi, Y., A. Nerd and P. S. Nobel. 1997. Cacti as crops. Horticultural Review, 18: 291-320.

Morton, J. f. 1987. Fruits of warm climates. Strawberry Pear. Florida Flair Books, Miami. pp. 347-348, 505.

Nerd, A., Gutman, F. and Mizrahi, Y. 1999. Ripening and postharvest behaviour of fruits of two Hylocereus species (Cactaceae). Postharvest Biology and Technology, 17 (1): 39-45.

Nobel, P. S. and E. de la Barrera. 2002. Stem water relations and wet $\mathrm{CO}_{2}$ uptake for a hemiepiphytic cactus during short term drought. Environmental and Experimental Botany, 48: 129-137.

Pushpakumara, D. K. N. G., Gunasena, H. P. M. and Kariayawasam, M. 2005. Flowering and fruiting phenology, pollination vectors and breeding system of dragon fruit ( Hylocereus spp.). Sri Lankan Journal of Agricultural Science, 42:81-91.

Rahim, M. A., S. A., Mithu, M. R. I., Titu, M. T., John, J. and Bhuya, M. A. H. 2009. Dragon Fhaler Chas Korun (Bengali). Bangladesh Agricultural University, Mymensingh and Swiss Foundation Development and International Cooperation, Paragon press ltd.

Taiwan Food Industry Development and Research Authorities. 2005. http//swarnabhumi.com/dragonfruit/health _benefits_of_dragonfruit.htm. 18 February, 2011.

Wikipedia.2012.http://en.wikipedia.org/wiki/Hyl ocereus_undatus. 12 October 2012. 